\title{
The Impacts of Foreign Bank Entry on Credit Scale and Business Structure of Chinese Commercial Banks*
}

\author{
Xiaoyan Huang, Yong Zeng \\ School of Management and Economics, University of Electronic Science and Technology of China, Chengdu, \\ China \\ E-mail: xiaoyan20071015@yahoo.cn,zengy@uestc.edu.cn \\ Received May 16, 2011; revised June 29, 2011; accepted July 18, 2011
}

\begin{abstract}
We employ a data set comprising 31 banks for the period 2002-2009 to investigate the impacts of foreign bank entry on credit scale and business structure in China. In this paper, foreign bank entry means the entry of both greenfield and strategic investment. The empirical results show that the foreign bank entry is not associated with the growth of credit scale, but significantly improves domestic banks' business structure. Furthermore, the network and informational advantages are the main considerations of foreign banks when entering into China through the mode of "minority equity stake”.
\end{abstract}

Keywords: Foreign Bank Entry, Credit Scale, Business Structure, Chinese Commercial Banks, Foreign Strategic Investors, Spillover Effect

\section{Introduction}

The banking system, as an essential part of Chinese financial system, has experienced unceasing reforms over the last three decades. It evidenced significant policy shifts around 1990, and 2001 when China joined WTO [1].

Before reforms begun in 1978, China had been very conservative in allowing the entry of foreign banks. In 1979, the Export-Import Bank of Japan become the first foreign bank allowed to open a representative office in Beijing, which is the prologue to the reform and opening-up of Chinese banking system [2]. In 1981, foreign banks were allowed to open operational branches in Special Economic Zones of China, which indicates the Chinese banking system had made substantial progresses. Then, Nanyang Commercial Bank, the first foreign bank opening operational branches in China, opened an operational branch in Shenzhen. In a word, there were not many foreign banks in China before 1990 because of the strict policy.

Since 1990, Chinese government has begun to allow foreign banks to enter more cities and to do business with Chinese enterprises by taking deposits and making loans in RMB. According to the Almanac of China's

\footnotetext{
*Supported by National Natural Science Foundation of China under Grant No. 70872016.
}

Finance and Banking, 190 operational branches had been opened by the end of $2001^{1}$. Besides, regulatory permission for foreign strategic investors to hold "minority equity stakes" ${ }^{2}$ in Chinese banks was forthcoming. The first case was in 1996, when Asian Development Bank (ADB) bought a 3.29\% stake in China Everbright Bank [2,3]. In 1999, International Finance Corporation (IFC) bought a $5 \%$ stake in Bank of Shanghai. This was followed by the purchase of a 15\% stake of Bank of Nanjing (Nanjing City Commercial Bank) by IFC and acquisition of an $8 \%$ stake in Bank of Shanghai by The Hong Kong and Shanghai Banking Corporation Limited (HSBC) at the end of 2001. To sum up, more foreign banks entered into China through varying entry modes at a relatively slow speed from 1990 to 2001.

On December 11, 2001, China gained entry into the World Trade Organization (WTO). New policies attracted more and more foreign banks and accelerated the

\footnotetext{
${ }^{1}$ Operational branches are defined by China Banking Regulatory Commission (CBRC), including head offices, branches, sub-branches and subsidiaries of stand-alone holding companies, and branches, sub-branches of foreign banks.

2“Administration of equity investment of overseas financial institutions in Chinese-funded financial institutions procedures Foreign" issued by CBRC rules that the percentage of equity investment of a signal overseas foreign institution in a Chinese-funded financial institution may not exceed $20 \%$, and the aggregate percentage of equity investment of multiple overseas financial institutions may not exceeds $25 \%$. We regard this situation as "minority equity stake".
} 
reform and opening-up of Chinese banking system. According to the Almanac of China's Finance and Banking, the number of greenfield banks had almost increased up to 600 by the end of 2009, almost three times of that in 2001. The total assets of foreign banks reached RMB 1.35 trillion, accounting for 1.71 percent of total banking assets in China. Meanwhile, according to the Annual Report of China Banking Regulatory Commission (CBRC), 31 Chinese commercial banks had introduced foreign strategic investors by the end of 2009.

After 1979, especially after WTO entry, policy shift accelerates the opening-up of Chinese banking system. More and more foreign banks have entered. However, the impacts of foreign bank entry are debatable. There are three kinds of viewpoints as follows. Firstly, foreign banks are regarded as "wolves" which will threat the existence of Chinese banks. Secondly, some people believe that the increasing number of foreign banks can intensify the banking competition, and spillover effects can be generated with the foreign bank entry. Both competition and spillover effects can improve the efficiency of Chinese banks. Thirdly, some people argue that, compared with Chinese banks, foreign banks are still small in scale, having little impact on China's banking industry. Aiming at this debatable situation, we make an empirical study to test the impact of foreign banks.

Our main empirical focuses are on credit scale and business structure. China's credit market attracts foreign banks because of its high interest spread. In addition, credit scale has significant impacts on macroeconomic and commercial banks. From the macroeconomic perspective, the flexible and controllable credit scale is the key of monetary policy. From the financing perspective, indirect financing accounts for a big share in China at present, that is to say bank loans are the main funds for enterprises. From the bank income structure, the share of non-interest income had been low for a long time and the income of banks mainly came from the interest spread. In summary, it is significant to study the impact of foreign bank entry on credit scale and business structure.

Loans are the main parts of both businesses and assets of Chinese commercial banks. However, with the development of banking system, the fast developing intermediate businesses are more important to banks. Business structure is defined as the ratio of credit to assets in this paper, and will affect the profitability, risk status and sustainability of banks. Therefore, we will also study the impact of foreign bank entry on business structure.

The remainder of the paper is organized as follows. Section 2 reviews literature. Section 3 discusses the design of our empirical study. Section 4 presents the empirical results and analysis. Section 5 provides conclusions. Section 6 and 7 are acknowledgement and refer- ences, respectively.

\section{Literature Review}

Based on credit scale studies, there are two different views on the impact of foreign bank entry on credit scale. Reference [4] shows that the entry of foreign banks can enlarge the total credit for 38 developing countries and long-term loans are less rate-constrained in countries with high foreign bank presence. Reference [5] finds that for East European countries the credit scales increase quickly with the entry of foreign banks and foreign bank entry improves access to credit for private sectors. Also, reference [6] finds that for Central European and Baltic countries, with the fierce competition on limited large enterprises and the promotion of screening ability on small and medium sized enterprises (SMEs), foreign banks improve access to credit for SMEs and even retail market. Reference [7] figures out that for countries with high presence of foreign banks, both large companies and SMEs face low financing obstacles.

However, the theoretic and empirical studies in [8] show that the entry of foreign banks reduces credit scale. Reference [9] finds that foreign banks tend to lend to big enterprises but not SMEs. Reference [10] shows that for East Europe, Latin America, Middle East and Asia countries that multinational banks only lend to multinational enterprises and high quality clients, and domestic banks are not able to lend to SMEs in order to avoid risk.

As for business structure studies, References [11,12] find that the entry of foreign banks reduces the ratio of non-interest income to whole income. Reference [13] shows that the same results based on panel data available for the 1994-2004 period of 14 banks in China. These studies suggest that foreign bank entry is not good for the adjustment of business structure. However, [14] makes an empirical test using monthly data available for the 1993-1995 period and finds that the ratio of loan to assets decreases with the increase of foreign bank presence, that is to say, foreign bank entry improves the business structure of domestic banks. Reference [15] finds that the foreign bank entry makes Chinese banks pay more attention to businesses besides deposits and loans.

To sum up, foreign bank entry has ambiguous effects on credit scale and business structure. Owing to a few studies on China's banking system, we make an empirical study on Chinese commercial banks.

\section{Empirical Analysis}

\subsection{Sample}

Since our focus is on China, we restrict our analysis to 
the Chinese commercial banks. The number of samples is 31 . We divide the samples into two types, namely domestic banks with and without foreign investment. Table $\mathbf{1}$ gives the abbreviations for samples and the years of the first entry of foreign investment. More than 99 percent of commercial banks' assets are in the 31 samples, so the samples can stand for the whole commercial banks.

The data set for the period from 2002 to 2009 in this paper is provided by Bank-scope database, Almanac of China's Finance and Banking, China Statistical Yearbook and Annual Report of CBRC. Test indicators are credit scale and business structure, measured by the growth of loan and the ratio of loan to assets, respectively.

We compare the difference of credit scale and business structure between the Chinese banks with or without foreign investment using the method of [1]. Table 2 gives the results of descriptive statistics. It can be found that there is no significant difference in credit scale and business structure between the two types of banks.

\subsection{Variables and Models}

In order to investigate the effects of foreign bank entry on credit scale and business structure of domestic banks, we need variables that measure the greenfield and strategic investment. In line with [11], we use two different variables to measure the presence of foreign banks through greenfield investment. First, we take the share of foreign bank assets to total bank assets of China ( $F B A$ ). This measure takes into account the size of foreign banks as compared to their domestic counterparts. Second, we adopt the ratio of the number of foreign banks to the total number of banks in China ( FBN ). This measure basically looks at the sheer presence of foreign banks. Both variables are calculated based on the data set provided by the Almanac of China's Finance and the Banking and Annual Report of CBRC. Finally, we take a dummy variable POST to measure foreign strategic investment.

Some foreign banks enter into China through greenfield approach as well as by "minority equity stake". That is to say, some of greenfield banks may be not only greenfield banks but also foreign strategic investors.

Table 1. List of sample banks.

\begin{tabular}{|c|c|c|c|c|c|c|c|}
\hline \multicolumn{8}{|c|}{$\begin{array}{l}\text { The abbreviations for banks with foreign investment and the years of } \\
\text { the first entry of foreign investment }\end{array}$} \\
\hline Abbr. & Time & Abbr. & Time & Abbr. & Time & Abbr. & Time \\
\hline $\mathrm{BSH}$ & 2001 & BNJ & 2001 & SPDB & 2002 & CIB & 2003 \\
\hline BOCOM & 2004 & SDB & 2004 & QLB & 2004 & HZB & 2005 \\
\hline BOC & 2005 & BOB & 2005 & CCB & 2005 & HXB & 2005 \\
\hline CQB & 2006 & ICBC & 2006 & GDB & 2006 & NBB & 2006 \\
\hline CITIC & 2006 & BQD & 2007 & YTB & 2008 & XMB & 2008 \\
\hline \multicolumn{8}{|c|}{ The abbreviations for banks without foreign investment } \\
\hline \multicolumn{2}{|c|}{$\mathrm{ABC}$} & \multicolumn{2}{|c|}{ PAB } & \multicolumn{2}{|c|}{$\mathrm{BNC}$} & \multicolumn{2}{|c|}{ QSB } \\
\hline \multicolumn{2}{|c|}{ CMBC } & \multicolumn{2}{|c|}{ BODG } & \multicolumn{2}{|c|}{ BODL } & \multicolumn{2}{|c|}{ CEB } \\
\hline \multicolumn{2}{|c|}{ CMB } & \multicolumn{2}{|c|}{ HKB } & \multicolumn{2}{|c|}{ BOW } & & \\
\hline
\end{tabular}

Note: Foreign investment is regarded as strategic one when the percentage of equity investment of foreign institution(s) in a Chinese financial institution is equal to or exceeds $5 \%$ in this paper. BSH is Bank of Shanghai. BNJ is Bank of Nanjing Co., LTD. SPDB is Shanghai Pudong Development Bank Co., Ltd. CIB is Industrial Bank Co., LTD. BOCOM is Bank of Communication. SDB is Shenzhen Development Bank Co., Ltd. QLB is Qilu Bank. HZB is Bank of Hangzhou. BOC is Bank of China. BOB is Bank of Beijing Co., Ltd. CCB is China Construction Bank. HXB is Huaxia Bank Co., Ltd. CQB is Bank of Chongqing. ICBC is Industrial and Commercial Bank of China Limited. GDB is Guangdong Development Bank. NBB is Bank of Ningbo Co., Ltd. CITIC is China CITIC Bank. BQD is Qingdao Bank. YTB is Yantai Bank. XMB is Xiamen Bank. ABC is Agricultural Bank of China. PAB is Pingan Bank. BNC is Bank of Nanchang. QSB is Qishang Bank. CMBC is China Minsheng Banking Corp., Ltd. BODG is Bank of Dongguan. BODL is Bank of Dalian. CEB is China Everbright Bank. CMB is China Merchants Bank Co., Ltd. HKB is Hankou Bank. BOW is Bank of Wenzhou.

Table 2. Descriptive statistics.

\begin{tabular}{|c|c|c|c|c|c|c|c|}
\hline Indicator & Variable & Mean & Median & SE & Maximum & Minimum & Samples \\
\hline \multirow{3}{*}{ Loan growth } & All & 24.01 & 21.89 & 17.11 & 83.50 & -36.61 & 233 \\
\hline & Second type & 23.34 & 22.09 & 16.15 & 70.69 & -36.62 & 79 \\
\hline & The difference & $\begin{array}{c}1.02 \\
(0.67)\end{array}$ & $\begin{array}{l}-0.45 \\
(0.91)\end{array}$ & & & & \\
\hline \multirow{4}{*}{ Loans/assets } & All & 53.72 & 53.45 & 7.57 & 71.1989 & 31.99 & 237 \\
\hline & First type & 53.41 & 52.48 & 7.58 & 71.1989 & 31.99 & 156 \\
\hline & Second type & 54.31 & 55.80 & 7.55 & 68.9186 & 37.22 & 81 \\
\hline & The difference & $\begin{array}{l}-0.90 \\
(0.39)\end{array}$ & $\begin{array}{l}-3.32 \\
(0.27)\end{array}$ & & & & \\
\hline
\end{tabular}

Note: The difference statistical tests of mean and median are analyzed by T test and Wilcoxon/Mann-Whitney rank test, respectively. The values in brackets are corresponding P values. "All” is the whole sample. "First type" is banks with foreign investment. "Second type" is banks without foreign investment. "The difference" is the difference between the two types of bank. 
Thus, in order to separate the effect of foreign strategic entry from that of the greenfield entry, and avoid multicolinearity, we use the residual (Resid) of the variable $F B$ regressed on the dummy POST to replace $F B$ in the multinomial regression.

We first study the impact of foreign bank entry on the credit scale and model the growth of credit as a function of the presence of foreign banks or foreign strategic investors, as well as control for ownership, bank characteristics, and macroeconomic environment. We construct the following two random effect (RE) panel data models:

$$
\begin{aligned}
L_{i, t}=\alpha & +\beta F B_{t}+\gamma_{1} \text { FSI }_{i}+\gamma_{2} \text { Ownership }_{i} \\
+ & \gamma_{3} \text { Bank characteristics }_{i, t}+\gamma_{4} \text { Macro }_{t}+\mu_{i}+\varepsilon_{i, t} \\
L_{i, t}= & \alpha+\beta_{1} \text { Resid }_{i, t}+\beta_{2} \text { FSI }_{i}+\beta_{3} \text { POST }_{i, t} \\
& +\gamma_{1} \text { Ownership }_{i}+\gamma_{2} \text { Bank characteristics }_{i, t} \\
& +\gamma_{3} \text { Macro }_{t}+\mu_{i}+\varepsilon_{i, t}
\end{aligned}
$$

where $L_{i, t}$ is the credit scale- the credit growth of bank $i$ in year $t ; F B_{t}$ is the presence of foreign banks, and includes $F B A_{t}$ and $F B N_{t} ; F S I_{i}$ is a dummy variable that captures the difference of the two types of domestic banks; $P O S T_{i, t}$ is a dummy variable that captures the effect of foreign strategic investors; Ownership $p_{i}$ are dummy variables $\left(J S C B_{i}\right.$ and $C C B_{i}$ ) that capture the effect of bank ownership (state-owned, joint-stock or city); Bank characteristics ${ }_{i, t}$ are variables that control for bank assets scale ( SIZE ), risk level ( NPL ), business model ( NIM ), capital constraint ( $R E G$ ), and growth of deposit (TD) for bank $i$ at $t$. Macro $i$ are variables that control for money supply ( $M 2$ - the growth of money supply), the degree of market competition (CR4) at time t. Resid ${ }_{i, t}$ is the substitution of the presence of foreign banks, and includes FBAResid $_{i, t}$ and FBNResid ${ }_{i, t} . \mu_{i}$ is the panel-level random effect. $\varepsilon_{i, t}$ is the random error term.

Before conducting the test on the effect of foreign entry on business structure, we make a Granger Causality Estimation between the presence of foreign banks and the ratio of loans to assets to grasp the relationship between the greenfield banks and business structure. We adopt a unit root test of the variables, and the results indicate that they are stationary. Table $\mathbf{3}$ gives the results

Table 3. The results of Granger causality estimation.

\begin{tabular}{lrccc}
\hline \multicolumn{2}{c}{ Null hypothesis $\backslash$ P value } & Lag 1 & Lag 2 & Lag 3 \\
\hline$B S$ does not Granger Cause & $F B N$ & 0.1867 & 0.6181 & $0.0620^{*}$ \\
$F B N$ does not Granger Cause & $B S$ & $0.0798^{* *}$ & $0.0223^{* * *}$ & $0.0022^{* * *}$ \\
BS does not Granger Cause & $F B A$ & $0.0139^{* * *}$ & 0.5666 & 0.5468 \\
$F B A$ does not Granger Cause & $B S$ & $0.0000^{* * *}$ & $0.0001^{* * *}$ & $0.0003^{* * *}$ \\
\hline
\end{tabular}

Note: ${ }^{* * *}$ Significant at the 0.01 level. ${ }^{* *}$ Significant at the 0.05 level. ${ }^{*}$ Significant at the 0.10 level. of Granger Causality Estimation.

The results of Granger Causality Estimation show that the entry of greenfield banks is the Granger cause of business structure. We use one period lag of variables $B S$ and $F B$, and construct the following models:

$$
\begin{aligned}
\text { BS }_{i, t}=\alpha & +\beta_{1} F_{t}+\beta_{2} F_{t-1}+\gamma_{1} F I_{i} \\
+ & \gamma_{2} \text { Ownership }_{i}+\gamma_{3} \text { Bank characteristics }_{i, t} \\
+ & \gamma_{4} \text { Macro }_{t}+\gamma_{5} B S_{i, t-1}+\mu_{\mathrm{i}}+\varepsilon_{i, t} \\
\text { BS }_{i, t}= & \alpha+\beta_{1} \text { Resid }_{i, t}+\beta_{2} \text { Resid }_{i, t-1}+\beta_{3} \text { FSI }_{i} \\
& +\beta_{4} \text { POST }_{i, t}+\gamma_{1} \text { Ownership }_{i} \\
& +\gamma_{2} \text { Bank characteristics }_{i, t}+\gamma_{3} \text { Macro }_{t} \\
& +\gamma_{4} \text { BS }_{i, t-1}+\mu_{\mathrm{i}}+\varepsilon_{i, t}
\end{aligned}
$$

where $B S_{i, t}$ is the business structure- the ratio of loans to assets; $F B_{t-1}, B S_{i, t-1}$ and Resid ${ }_{i, t-1}$ are lagged variables by one period of $F B_{t}, B S_{i, t}$ and Resid ${ }_{i, t}$, respectively. In Equations (3) and (4), Resid ${ }_{i, t}, F S I_{i}, P O S T_{i, t}$

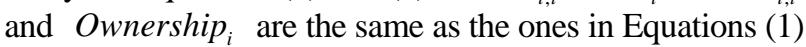
and (2). Bank characteristics ${ }_{i, t}$ includes SIZE , NPL, $N I M$, and REG. Macro ${ }_{i}$ refers to M2. $\mu_{i}$ is the panel-level random effect. $\varepsilon_{i, t}$ is the random error term. All the variables in this paper are given in Table 4.

\section{Empirical Results}

We estimate Equations (1)-(4) using Eviews 6.0. Table 5 shows the estimation results.

Compared with other Chinese banks, 5 state-owned banks have such features as large size, high market share and historical problems left behind. Therefore, we make a robust test using samples except 5 state-owned banks, and the results are consistent with Table 5. Therefore, the empirical analysis is robust.

Table 5 suggests that the presence of foreign banks is not associated with credit scale. The reason is that foreign banks have some competitive disadvantages in China's credit market. Although foreign banks have developed fast since China entered WTO, the assets scale and number of foreign banks are small compared with domestic banks, and foreign banks lack branch networks and funds. According to the 2010 Report of Price Waterhouse Coopers (PwC) "Foreign banks in China", the funds of foreign banks in China mainly come from their parent banks, deposits and interbank lending. That is to say, foreign banks' funds are limited. For example, according to the Shanghai Statistical Yearbook, during 2002-2009 the deposit market share of all foreign banks in Shanghai, the city with the highest presence of foreign banks in China, is still less than $10 \%$. Branch networks and funds are the basement to engage in loans for banks. 
Table 4. List of variables.

\begin{tabular}{|c|c|}
\hline Variable & Definition or calculation formula \\
\hline$L$ & Growth of loan \\
\hline$B S$ & Ratio of loan to assets \\
\hline \multirow{2}{*}{$F B$} & Share of foreign bank assets to total bank assets of China $F B A$ \\
\hline & Ratio of the number of foreign banks to the total number of banks in China $F B N$ \\
\hline Resid & Resid is the residual of FB regressed on POST. \\
\hline FSI & FSI is 1 for banks with foreign investment, and 0 for others. \\
\hline POST & POST is 0 before and in the year when Chinese banks introduced foreign investment, and 1 other years. \\
\hline$J S C B$ & $J S C B$ is 1 for joint-stock commercial banks, and 0 for others. \\
\hline CCB & $C C B$ is 1 for city commercial banks, and 0 for others. \\
\hline SIZE & Ratio of bank assets to the total assets of banking system ${ }^{1}$ \\
\hline$N P L$ & Ratio of impaired loans to gross loans \\
\hline$R E G$ & $R E G$ is 1 when the last year total capital ratio is below $8 \%$, and 0 others. \\
\hline NIM & Denoting business model of banks \\
\hline$T D$ & Growth of deposit \\
\hline$M 2$ & Growth of money supply \\
\hline CR4 & Share of the largest 4 commercial banks' deposits to the total deposits of banking system² \\
\hline
\end{tabular}

1. SIZE is calculated in line with [16]. 2. The reason of choosing the share of deposits as market concentration is that deposits are the main business and the basement of other businesses for banks.

These disadvantages go against foreign banks. However, foreign banks have much superiority on international businesses. According to statistics, foreign banks in China mostly come from the countries or areas frequently trading with China such as Hong Kong, Japan, Singapore, Korea, Britain, French, American and Canada, etc. And they always enter into developed cities like Shanghai, Shenzhen, Beijing, Guangzhou, Tianjin and Xiamen, which are the earliest regions opened to foreign banks and export-oriented economic regions. Table 6 lists the total volume of export and import, the assets and number of foreign banks during the period of 2002-2008. It is obvious that they are positively correlated. From Table 6, the distributions of original countries or areas and objective cities, we can see that serving the multinational enterprises and the trade with China are the main motivation for foreign banks to enter into China. References [17-19] show that service for trade by following their customers is an important factor for foreign banks to decide whether or not to enter one city. Weighting the advantages and disadvantages, foreign banks will almost lend to their home country enterprises and global enterprises in credit market, so the presence of foreign banks has no significant effects on credit scale. PwC's Report also indicates that both global and home country enterprises remain significant to the loan portfolio of foreign banks in China.
Table 5 suggests that the presence of foreign banks is associated with business structure. This could be attributed to spillover effects with the foreign bank entry. Reference [12] finds that spillover effects come into being when foreign banks enter into less-developed countries, and the bigger the difference between the banking systems of home and host countries is, the more positive the spillover effects are. It is obvious that the business structure of foreign banks' parents is superior to that of Chinese banks, but we need to test whether the business structure of greenfield banks is the same as their parents. The left three columns of Table 7 give the test result, which indicates that they are significantly different. The features of Chinese banking system, such as attractively high interest spread, investors' lack of knowledge, and constraint on business scope for foreign banks, make the difference. In China, high interest spread attracts foreign banks and makes them try their best to fight for loan market share. Moreover, lack of knowledge and constraint of foreign banks' business scope prevent foreign banks from carrying out some businesses which are mature in their home countries. However, we cannot deny that greenfield banks own the advantages in businesses, such as advanced techniques, management ideas and talents. Greenfield banks can attract customers by improving service quality and supplying differential products in the permitted business range, so they do not com- 
Table 5. Foreign bank presence and credit scale and business structure in China.

\begin{tabular}{|c|c|c|c|c|c|c|c|c|}
\hline \multirow{2}{*}{$\begin{array}{c}\text { Dependent } \\
\text { variable }\end{array}$} & \multicolumn{4}{|c|}{ Credit Scale } & \multicolumn{4}{|c|}{ Business Structure } \\
\hline & \multicolumn{2}{|c|}{ (1) } & \multicolumn{2}{|c|}{$(2)$} & \multicolumn{2}{|c|}{ (3) } & \multicolumn{2}{|c|}{ (4) } \\
\hline Method & \multicolumn{4}{|c|}{ Random-effects model, Panel EGLS } & \multicolumn{4}{|c|}{ Random-effects model, Panel EGLS } \\
\hline C & -32.2169 & $-82.4452^{* * *}$ & -47.9996 & $-84.1431^{* * *}$ & $23.2136^{* * *}$ & $14.2199^{* * *}$ & $10.7589^{* *}$ & 5.6680 \\
\hline$F B A$ & -8.2626 & & & & $-4.4957^{*}$ & & & \\
\hline FBAResid & & & -8.5405 & & & & $-4.5047^{*}$ & \\
\hline$F B N$ & & -2.2398 & & & & $-33.3535^{* * *}$ & & \\
\hline FBNResid & & & & -2.3213 & & & & $-9.3460^{* *}$ \\
\hline FSI & -2.5681 & -2.6812 & -3.0529 & -2.9127 & -0.3356 & -0.2574 & -0.0787 & 0.2428 \\
\hline POST & & & -1.0251 & -0.1874 & & & $-1.6694^{* * *}$ & $-2.6611^{* * *}$ \\
\hline$J S C B$ & -0.8838 & -0.9119 & -0.8226 & -0.8813 & 1.0665 & 1.2079 & 1.0153 & 1.1847 \\
\hline$C C B$ & -1.6410 & -1.7898 & -1.5088 & -1.7278 & -0.9425 & -1.1527 & -1.0348 & -1.3239 \\
\hline SIZE & -0.3880 & -0.3988 & -0.3786 & -0.3943 & -0.2139 & -0.2312 & -0.2201 & -0.2417 \\
\hline$N P L$ & $-0.6168^{* * *}$ & $-0.6298^{* * * *}$ & $-0.6217^{* * *}$ & $-0.6322^{* * *}$ & 0.1116 & $0.1566^{* *}$ & 0.1130 & $0.1515^{* *}$ \\
\hline NIM & 0.9478 & 0.7176 & 0.9188 & 0.7027 & $1.4776^{* * *}$ & $1.7234^{* * *}$ & $1.4665^{* *}$ & $1.5969^{* * *}$ \\
\hline$R E G$ & -1.7501 & -1.6262 & -1.6157 & -1.5625 & -0.4058 & -0.6133 & -0.4841 & -0.6958 \\
\hline$T D$ & $0.5581^{* * * *}$ & $0.5411^{* * * *}$ & $0.5542^{* * *}$ & $0.5390^{* * * *}$ & & & & \\
\hline M2 & $0.9880^{* *}$ & $1.5233^{* * *}$ & $0.9734^{* *}$ & $1.5256^{* * *}$ & 0.1395 & 0.0827 & 0.1359 & $0.4784^{* * *}$ \\
\hline$C R 4$ & $0.7019^{*}$ & $1.1098^{* * * *}$ & $0.7212^{*}$ & $1.1237^{* * *}$ & & & & \\
\hline$F B A(-1)$ & & & & & -2.4054 & & & \\
\hline FBAResid(-1) & & & & & & & -2.1345 & \\
\hline$F B N(-1)$ & & & & & & $33.0192^{* * *}$ & & \\
\hline FBNResid(-1) & & & & & & & & 1.9228 \\
\hline$B S(-1)$ & & & & & $0.7061^{* * *}$ & $0.6896^{* * *}$ & $0.7087^{* * *}$ & $0.6801^{* * *}$ \\
\hline $\operatorname{Adj} . R^{2}$ & 0.6697 & 0.6652 & 0.6679 & 0.6631 & 0.7409 & 0.7442 & 0.7392 & 0.7342 \\
\hline
\end{tabular}

${ }^{* * *}$ Significant at the 0.01 level. ${ }^{* *}$ Significant at the 0.05 level. ${ }^{*}$ Significant at the 0.10 level.

Table 6. Foreign banks' scale and total volume of export and import.

\begin{tabular}{cccccccc}
\hline Item & 2002 & 2003 & 2004 & 2005 & 2006 & 2007 & 2008 \\
\hline Total volume of export and import (billions) $^{1}$ & 5137.8 & 7048.4 & 9553.9 & 11692.2 & 14097.2 & 16674.0 & 17992.2 \\
Total assets of foreign banks in China (billions) & 324.08 & 415.97 & 582.29 & 715.45 & 927.87 & 1252.47 & 1344.78 \\
The number of foreign banks in China & 180 & 192 & 211 & 254 & 312 & 440 & 558 \\
\hline
\end{tabular}

1. Total volume of export and import is the sum of goods actually crossing Chinese border. Source includes China Statistical Yearbook, Almanac of China's Finance and Banking and China Banking Regulatory Commission’s Annual Reports.

Table 7. Difference tests in business structure.

\begin{tabular}{cccccc}
\hline Variable & Mean & Median & Variable & Mean & Median \\
\hline Foreign banks' parents & 44.628 & 43.999 & Foreign strategic investors & 44.845 & 45.700 \\
Foreign banks in China & 61.498 & 64.450 & Chinese banks with foreign equity & 53.408 & 52.479 \\
& $-16.870^{* * *}$ & $-20.451^{* * *}$ & \multirow{2}{*}{ The difference between the two types } & $-8.563^{* * *}$ & $-6.779^{* * *}$ \\
The difference between the two types & $(0.000)$ & $(0.0000)$ & & $(0.000)$ & $(0.000)$ \\
& & & \\
\end{tabular}

Note: The difference statistical tests of mean and median are analyzed by T test and Wilcoxon/Mann-Whitney rank test, respectively. The values in brackets are corresponding P values. ${ }^{* * *}$ Significant at the 0.01 level.

pete with Chinese banks in all businesses but intermedi- ate businesses at first. Therefore, foreign bank entry en- 
hances the quantity and diversity of financial product supply. Advanced techniques and management ideas enter into market with new financial service and products, and then Chinese banks can learn and use them to speed up financial product innovation and improve business structure. Reference [20] shows that the ratio of noninterest income to total operating income has been increased during 2002-2007. That is to say, the income structure of Chinese commercial banks has greatly changed. And according to the annual reports of 4 stateowned banks in 2009, the ratio of Bank of China (BOC) is the highest among Chinese banks and reaches $31.58 \%$. PwC's 2010 report also mentions that it is difficult to distinguish the products between foreign banks and Chinese banks. Thus, the development speed of intermediate businesses and the adjustment effect of business structure are fast and obvious, respectively.

We can see that dummy variable FSI is not significantly correlative with dependent variables from Table 5. That means foreign strategic investors do not care the credit scale and business structure of their partners. On December 11, 2001, China joined WTO and promised to open banking industry to foreign banks without limitation from December 11, 2006. During the 5 transitional years there are many advantages in "equity stake" entry mode. Firstly, foreign strategic investors can avoid the limitation of customers, geographical and operational scope, and utilize the networks of domestic banks to interfere in some areas not open to them yet in advance. For example, the Pacific Credit Card Center of BOCOM established according to the cooperation agreement between BOCOM and HSBC, makes HSBC avoid the constraint on customers and location in RMB, and enter RMB retail market ahead of time. Secondly, foreign banks enter into eastern developed regions at first through greenfield investment. However, other regions are also amazing, so they share domestic banks' profit through "minority equity stake". Moreover, foreign strategic investors can gain the informational advantage by cooperating with domestic banks, which is an important factor researched by references such as [21]. To sum up, foreign strategic investors consider the advantages of the "minority equity stake" entry mode rather than the credit scale and business structure of their copartners, so the coefficient of dummy variable FSI is not significant naturally.

We can also see that dummy variable POST is not significantly correlative with credit scale from Table $\mathbf{5}$. The coefficients of POST for credit scale are not significant, that means the credit scale of Chinese banks does not change significantly after foreign investment. The reason is that the strategic cooperation agreements, signed by Chinese banks and their foreign strategic in- vestors, do not refer to loan. For instance, the strategic cooperation agreement between CCB and Bank of America (BOA) required BOA to provide strategic supports in risk management, corporate governance, credit card, private bank, global service, information technology, and so on. Obviously, foreign strategic investors are not helpful in loans. Therefore, it is natural that the credit scale has no significant change after the cooperation.

From Table 5 we can know that dummy variable POST is significantly correlative with business structure. Consistent findings are reported by [22]. The right three columns of Table 7 indicate that the business structure of foreign strategic investors is significantly better than that of Chinese banks. It is the foreign strategic investors that affect the innovation ability and even business structure of domestic banks through their strategic cooperation agreements. According to the cooperation agreements, foreign investors provide managers, experts, resources and technology, etc., to their cooperators. On the one hand, resources and technology can directly push the innovation of domestic banks. On the other hand, managers from foreign investors may shift management ideas and business strategy of domestic banks by participating in their management and decision. This indirectly promotes the innovation ability of domestic banks. In short, the entry of foreign strategic investors is helpful in improving the business structure of domestic banks.

Finally, we analyze capital adequacy ratio, money supply and market concentration. If capital adequacy ratio is below $8 \%$, banks will feel pressure and limit the business scope to improve the capital adequacy ratio, so regulatory pressure is not good for the adjustment of business structure or the growth of loan. Reference [23] also indicates that capital constraint has negative effect on loan. Money supply and market concentration both have significantly positive correlation with credit scale. That is to say, the factors affecting the credit scale are macro-economic and bank characteristics rather than foreign bank entry.

According to the empirical analysis above, we know the impacts of greenfield banks and foreign strategic investors are consistent. From the way of greenfield, none of foreign or domestic banks have absolute advantage. The comparative advantages of greenfield banks make themselves avoid the fierce competition on credit market and develop their advantage on other businesses. From the way of "minority equity stake", the strategic cooperation between foreign strategic investors and domestic banks is helpful to the promotion of business structure of domestic banks. Summarily, Chinese banks are not impacted in traditional credit market but they can get help and learn from foreign banks in other markets. Therefore, foreign bank entry is helpful in the improve- 
ment of innovation ability and the adjustment of business structure of domestic banks.

\section{Conclusions}

This paper investigated the impacts of two different ways of foreign bank entry on credit scale and business structure of Chinese commercial banks, based on the banklevel panel data available for the 2002-2009 period. The empirical results show that the foreign bank entry is not associated with the growth of credit scale, but significantly improves domestic banks' business structure. In short, the foreign bank entry is useful to the improvement of innovation ability and the adjustment of business structure of Chinese commercial banks. This conclusion also partially indicates the effect of the reform and opening-up of Chinese banking system.

\section{Acknowledgements}

This research has been supported by grants from the National Natural Science Foundation of China (No. 70872016).

\section{References}

[1] A. N. Berger, I. Hasan and M. M. Zhou, "Bank Ownership and Efficiency in China: What Lies ahead in the World's Largest Nation,” Bank of Finland Research Discussion Paper, No. 16, 2007.

[2] H. J. Song, "Research of China's Strategy to Cope with Entry of Foreign Banks (Chinese),” Master Thesis, East China Normal University, Shanghai, 2010.

[3] Y. Y. Zhu, Y. Zeng, P. Li and J. He, "Introducing the Overseas Strategic Investors into Chinese Banks: Backgrounds, Disputes and Reviews (Chinese),” Management World, Vol. 1, 2008, pp. 21-56.

[4] G. R. G. Clarke, R. Cull and M. S. M. Peria, "Does Foreign Bank Penetration Reduce Access to Credit in Developing Countries? Evidence form Asking Borrowers,” World Bank Policy Research Working Paper, Vol. 2716, 2001, pp. 22-25.

[5] S. Claeys and C. Hainz, "Foreign Banks in Eastern Europe: Mode of Entry and Effects on Bank Interest Rates," Governance and the Efficiency of Economic Systems Discussion Paper, No. 95, 2006.

[6] R. De Haas and I. Naaborg, "Foreign Banks in Transition Countries: To Whom do They Lend and How are They Financed,” Finance Markets, Institutions \& Instruments, Vol. 15, No.4, 2006, pp. 159-199. doi:10.1111/j.1468-0416.2006.00116.x

[7] G. R. G. Clarke, R. Cull and M. S. M. Peria, "Foreign Bank Participation and Access to Credit across Firms in Developing Countries," Journal of Comparative Economics, Vol. 34, No. 4, 2006, pp. 774-795. doi:10.1016/j.jce.2006.08.001

[8] E. Detragiache, T. Tressel and P. Gupta, "Foreign Banks in Poor Countries: Theory and Evidence," The Journal of Finance, Vol. 63, No. 5, 2008, pp. 2123-2160. doi:10.1111/j.1540-6261.2008.01392.X

[9] R. Sengupta, "Foreign Entry and Bank Competition,” Journal of Financial Economics, Vol. 84, No. 2, 2007, pp. 502-528. doi:10.1016/j.jfineco.2006.04.002

[10] C. E. Weller and M. J. Scher, "Multinational Banks and Development Finance,” ZEI Working Paper B99-16, Center for European Integration Studies, University of Bonn, 1999.

[11] S. Claessens, A. Demirguc-Kunt and H. Huizinga, "How does Foreign Entry Affect the Domestic Banking Market," Journal of Banking and Finance, Vol. 25, No.5, 2001, pp. 891-911. doi:10.1016/S0378-4266(00)00102-3

[12] R. Lensink and N. Hermes, "The Short-Term Effects of Foreign Bank Entry on Domestic Bank Behaviour: Does Economic Development Matter,” Journal of Banking \& Finance, Vol. 24, No. 3, 2004, pp. 553-568. doi:10.1016/S0378-4266(02)00393-X

[13] X. F. Li, W. Wang and J. J. Yan, "The Effect of Foreign Entry on the Efficiency of Domestic Banking in China: Empirical Analysis (Chinese)," Finance \& Economics, Vol. 8, 2006, pp. 16-23.

[14] C. E. Weller, "Financial Liberalization, Multinational Banks and Credit Supply: The Case of Poland,” International Review of Applies Economics, Vol. 14, No.2, 2000, pp. 193-211. doi:10.1080/02692170050024741

[15] D. F. Xu and Q. S. Feng, "The Effect of Foreign Bank Entry on Domestic Banking in China: Empirical Analysis (Chinese)," Contemporary Economics, Vol. 1, 2009, pp. 152-153.

[16] Y. Y. Zhu, Y. Zeng, P. Li and J. He, "Foreign Strategic Investors' Participation, Bank Restructuring and Chinese Banks’ Credit Risk (Chinese),” 2009 China International Conference in Finance (CICF2009), Guangzhou, 7-10 July 2009.

[17] H. J. Zhang and Z. J. Yang, "Reason Analysis on Location Distribution of Foreign Banks in China's Market (Chinese)," Journal of Finance, Vol. 9, 2007, pp. 160172.

[18] Q. H. Miao and H. P. Wang, “An Empirical Study of Investment Motivation of Foreign Banks in China (Chinese),” Shanghai Finance, Vol. 8, 2004, pp. 9-11.

[19] H. J. Zhang and Z. L. Zheng, "Study on the Reasons of Foreign Bank Entering Chinese Market-Based on Phases Panel Data (Chinese)," Finance \& Trade Economics, Vol. 4, 2009, pp. 45-51.

[20] D. H. Yang, "Development Process of Intermediary Business of Chinese Commercial Banks from the Perspective of the Profit Structure (Chinese)," Financial Accounting, Vol. 8, 2009, pp. 40-45.

[21] B. Zhang, Y. Zeng and Q. Li, "Market Characteristics and the Entry Modes of Foreign Banks," The $8^{\text {th }}$ International Conference on Risk Management \& Financial Sys- 
tems Engineering (RMFSE2010), Beijing, 16-17 October 2010.

[22] Y. Y. Zhu, P. Li, Y. Zeng and J. He, "Capital, KnowHow and Systems: An Empirical Study on Introducing Foreign Strategic Investors into Chinese Banks (Chi- nese),” China Soft Science, Vol. 8, 2010, pp. 70-80.

[23] B. Liu, "Empirical Analysis of the Impact of Capital Adequacy Ratio on Bank Loans and Economic (Chinese)," Journal of Finance, Vol. 11, 2005, pp. 18-30. 